\title{
ワクチンと薬剤の併用で結核の 治癒を目指す
}

\section{Vaccine helps to banish tuberculosis}

news050131-12/3 February 200

Jessica Ebert

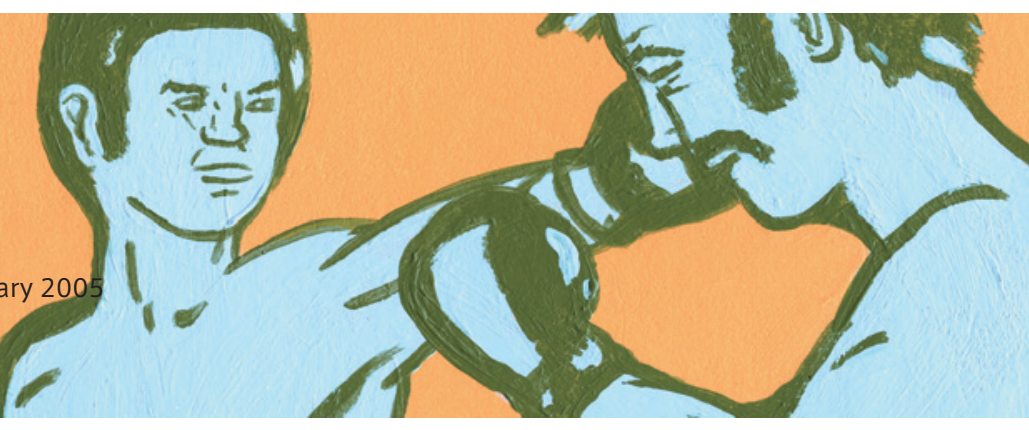

このほど発表されたマウスによる実験結果によって、薬剤耐性菌株の撲滅への希望が生まれている。

結核菌の DNA が含まれた結核ワク

チンを他の薬剤とともにマウスに投

与したところ結核が治癒した、と韓 国の研究者グループが報告した。薬 剤のみに頼る現在の方法よりも迅速 かつ効果的に作用する治療法となる のではないか、という希望が生まれ ている。

Mycobacterium tuberculosis という細菌を原因とする結核によっ て、世界中で年間およそ 200 万人が 命を落としている。単独の感染症に よる死者数としては最大である。結 核の症例数は、薬剤耐性菌株と HIV 感染症の出現によって、1985 年か ら増え始めた。AIDS 患者の死亡例の 13\% は結核が原因である。

薬剤耐性菌株の出現は、投与され た薬剂を途中でやめる患者が多いこ とのが原因の1つに挙げられる。結 核は、抗生物質の併用投与によっ て治療できるが、治療期間は最長 12 カ月を要する。もし患者が薬をや めるのが早すぎると、結核が再発す ることがある。
「現在の化学療法は、必要とされる レベルに達していない」。こう語る のは、国立医学研究所 ( 英国ロンド ン) で免疫学を研究するDouglas Lowrieだ。

必要とされているのは、比較的短 期間に体内から M. tuberculosis を 一掃し、新たな感染源による結核感 染を防止できるような治療法なのだ。 浦項科学技術大学 (韓国) の Youngchul Sungたちの研究グ ループは、マウスを使った実験で、 まさにこのような治療法を発見し、 その研究結果をGene Therapyに 報告した 1 。

結核菌にダブルパンチ

Sungたちは、2 種類の結核菌遺伝 子を含む実験的な DNA ワクチンを 作製した。結核にかかったマウスに 標準的な薬物治療を行う実験で、一 部のマウスにはその実験的ワクチン を併用した。

実験的ワクチンを併用せず、薬物 治療だけが行われたマウスの場合、
治療が終了すると細菌の数は増えた。 ワクチンを併用したマウスの場合に は、このような再発は見られなかっ た。また、ワクチンを併用した治療 では免疫応答が生じ、結核菌の再感 染率は有意な程度、減少した。

ワクチンと薬剤を併用した治療法 が、結核菌の消失を促進し、また再 感染を予防する効果もあることを明 らかにした研究は今回が初めてだ、 とLowrie は語っている。

これはマウスを使った実験結果だ が、この併用療法は「予想以上に早 く臨床現場に行き渡るかもしれない」 とLowrie は言う。多剂耐性の細菌 株の脅威が高まっているため、有望 な治療法については臨床試験を実施 したいという動きがあるからだ。

\footnotetext{
参考文献

1. Ha S.-J., et al. Gene Therapy published online (2005). doi:10.1038/ sj.gt.3302465
} 